Андрій Зельницький, кандидат педагогічних наук, професор Національний університет оборони України імені Івана Черняховського ORCID ID 0000-0002-3910-7329

DOI: $10.33099 / 2617-1775 / 2021-02 / 82-90$

\title{
ЗВОРОТНИЙ ЗВ' ЯЗОК ЯК КОМПОНЕНТ УПРАВЛІННЯ ЗМІНАМИ У СИСТЕМІ ВІЙСЬКОВОЇ ОСВІТИ
}

У статті визначено роль $і$ місие зворотного зв'язку в системі управління змінами військової освіти щуодо ї̈ переведення з поточного стану в необхідний (бажаний) стан в умовах впливу певних чинників зовнішнього та внутрішнього середовища, запропоновано підходи до формування змісту відгуку на випускника ЗВО як складової зворотного зв'язку та до оцінювання рівня сформованості визначених компетентностей і професійно важливих якостей у випускника за результатами його службової діяльності у військах (силах).

Ключові слова: управління змінами; освітній процес; зворотний зв'язок; заклади військової освіти; система військової освіти.

Постановка проблеми. Проблема управління змінами у системі військової освіти (далі - CВО) та зворотних зв'язків у ії функціонуванні постає як одна з пріоритетних і малодосліджених проблем щодо забезпечення якості підготовки військових фахівців для Збройних Сил України та інших військових формувань, утворених відповідно до законів України. Ї̈̈ актуальність обумовлена низкою чинників, а саме:

потребою оперативного реагування системи військової освіти на докорінні зміни у зовнішньому та внутрішньому освітньому середовищі;

необхідністю приведення військової освіти в Україні у відповідність до європейських та євроатлантичних освітніх стандартів;

потребою забезпечення якісно нового рівня підготовки здобувачів вищої військової освіти на принципах людиноцентризму, підвищення рівня їх практичної підготовленості до виконання функціональних обов'язків в умовах мирного і воєнного часу;

необхідністю перегляду діючих концептуальних положень у сфері військової освіти, що стримують ії подальший розвиток та розроблення нових сучасних концепцій.

недостатнім рівнем впровадження в педагогічну практику основ професіографічного, компетентнісного та кваліметричного підходів щодо вимірювання якості підготовки військових фахівців;

повільним впровадження в освітній процес сучасних інформаційних, інформаційно-комунікаційних технологій та методик;

законодавчою невнормованістю структури та змісту відгуків на випускників закладів військової освіти як компоненту управління змінами у системі військової освіти тощо.

Аналіз останніх досліджень і публікацій. Загальним проблемам освітніх систем присвячені наукові праці вітчизняних вчених-педагогів та психологів 
В. Андрущенка, С. Гончаренко, О. Жадька, В. Лугового, Л. Маргуліної, В. Рябенка, Є. Поліщук, а щодо вищої військової освіти - наукові праці А. Вітченка, В. Осьодла, Ю. Приходька, С. Салкуцана, В. Свистун, В. Телелима, П. Щипанського, В. Ягупова та ін., де розглядаються певні проблеми розвитку військової та вищої військової освіти.

Аналіз досліджень і публікацій згаданих авторів значною мірою сприяє виробленню наукових підходів до подальшого розвитку військової освіти та вирішенню проблеми щодо застосування зворотних зв'язків в системі управління військовою освітньою галуззю.

Мета статті - дослідити роль, місце і сутність зворотного зв'язку як складової процесу управління змінами у системі військової освіти та розглянути теоретичні основи вирішення даної проблеми.

Методи дослідження. Дослідження проведене із застосуванням таких теоретичних методів: системний аналіз i синтез, індукція та дедукція, порівняння, класифікація, узагальнення й систематизація.

\section{Виклад основного матеріалу.}

Зворотний зв'язок це обов'язкова складова процесу управління. Він має застосовуватися на всіх іiі етапах і стадіях. Його застосування дає можливість систематично відстежувати ефективність процесу та доцільність і обгрунтованість прийнятих рішень, відповідність отриманих результатів тим, що передбачалися, а також сприяє виявленню відхилень від запланованих параметрів та усуненню несприятливих наслідків функціонування системи.

Зворотний вв'язок (англ. feedback) - вплив результату функціонування будь-якої системи на характер iї подальшого функціонування. Термін “зворотний зв'язок” використовують стосовно перебігу процесів у соціальних, біологічних, технічних, економічних та інших системах, а також у кібернетиці та теорії автоматичного регулювання та управління.

Одне 3 перших досліджень впливу зворотного зв'язку на результат функціонування системи було виконане Майклом Фарадеєм у популярній роботі "Історія свічки". За характером впливу розрізняють позитивний та негативний зворотний зв'язок.

Позитивний зворотний зв'язок впливає на систему таким чином, що збільшує вихідний результат іï функціонування. У теорії автоматичного управління позитивний зворотний зв'язок реалізується шляхом передачі на вхід системи частини вихідного сигналу таким чином, що сигнал зворотного зв'язку збігається у фазі з вхідним сигналом, що є еквівалентним збільшенню вхідного сигналу. В окремих випадках позитивний зворотний зв'язок може призводити до генерації в системі - коли будь-яка флуктуація в системі передається на іiі вхід і підсилюється, завдяки чому в системі виникають незатухаючі коливання.

Негативний зворотний зв'язок впливає на систему таким чином, що зменшує вихідний результат iї функціонування. В теорії автоматичного управління негативний зворотний зв'язок реалізується шляхом передачі на вхід системи частини вихідного сигналу таким чином, що сигнал зворотного зв'язку знаходиться у протифазі з вхідним сигналом, що є еквівалентним зменшенню вхідного сигналу, що призводить до зниження коефіцієнта підсилення системи, 
але при цьому також підвищується стійкість системи та зменшується похибка та інерційність системи.

Отже, зворотний зв'язок $є$ однією 3 послідовно здійснюваних операцій управлінського циклу, у ході яких суб'єкт управління досягає бажаних результатів. Управлінський цикл являє собою сукупність послідовно здійснюваних управлінських операцій. У кожному циклі спостерігається певна послідовність управлінських дій. Додержання певного порядку їх виконання має важливе значення для забезпечення високої якості управління. Управлінський цикл можна схарактеризувати як процес, який поділяється на певні стадії, етапи, операції або окремі управлінські дії і процедури.

Перша процедура - формулювання мети. Операції: діагноз, прогноз, формулювання кінцевої мети, стратегія дії, конкретні завдання.

Друга процедура - прийняття рішення. Операції: виявлення проблемної ситуації, обгрунтування варіантів дії, вибір оптимального варіанта, затвердження рішення.

Третя процедура - організація соціальної дії. Операції: розподіл завдань між виконавцями, забезпечення виконавців, координація та регулювання процесу виконання, контроль.

Четверта процедура - аналіз результатів. Операції: зворотний зв'язок, зіставлення запланованих та досягнутих результатів, відкриття нових проблемних ситуацій, попереднє формулювання нової мети.

Управлінський цикл має повторюватися безперервно. Якщо була поставлена якась ціль або завдання, то ії досягнення (вирішення проблеми) завжди викликає нову ситуацію, що вимагає нових управлінських рішень.

Щодо зворотних зв'язків у системі військової освіти, то їх можна умовно розділити на два види. Перший - це зворотний зв'язок, що застосовується в межах освітнього процесу у закладах військової освіти (далі - ЗВО). Другий характеризує якість підготовки військових фахівців при виконанні ним службових обов'язків на посаді призначення у військах, (силах) після завершення навчання у 3ВО (Рис. 1).

Розглянемо більш уважно саме другий тип зворотного зв'язку, що передбачає отримання та аналіз закладами військової освіти та інших зацікавлених структур інформації з військ про проходження служби зазначеними вище військовими фахівцями. При цьому зробимо наголос на вирішення проблеми управління змінами в системі військової освіти за результатами аналізу відгуків на випускників.

Відповідно до представленої структури (Рис.1) на замовників та заклади військової освіти покладається відповідальність за виконання замовлення щодо кількісних та якісних показників підготовки військових фахівців зі ступенем сформованості в кожного 3 них необхідних компетентностей на визначеному рівні відповідно до вимог освітніх програм за певними спеціальностями (спеціалізаціями). 


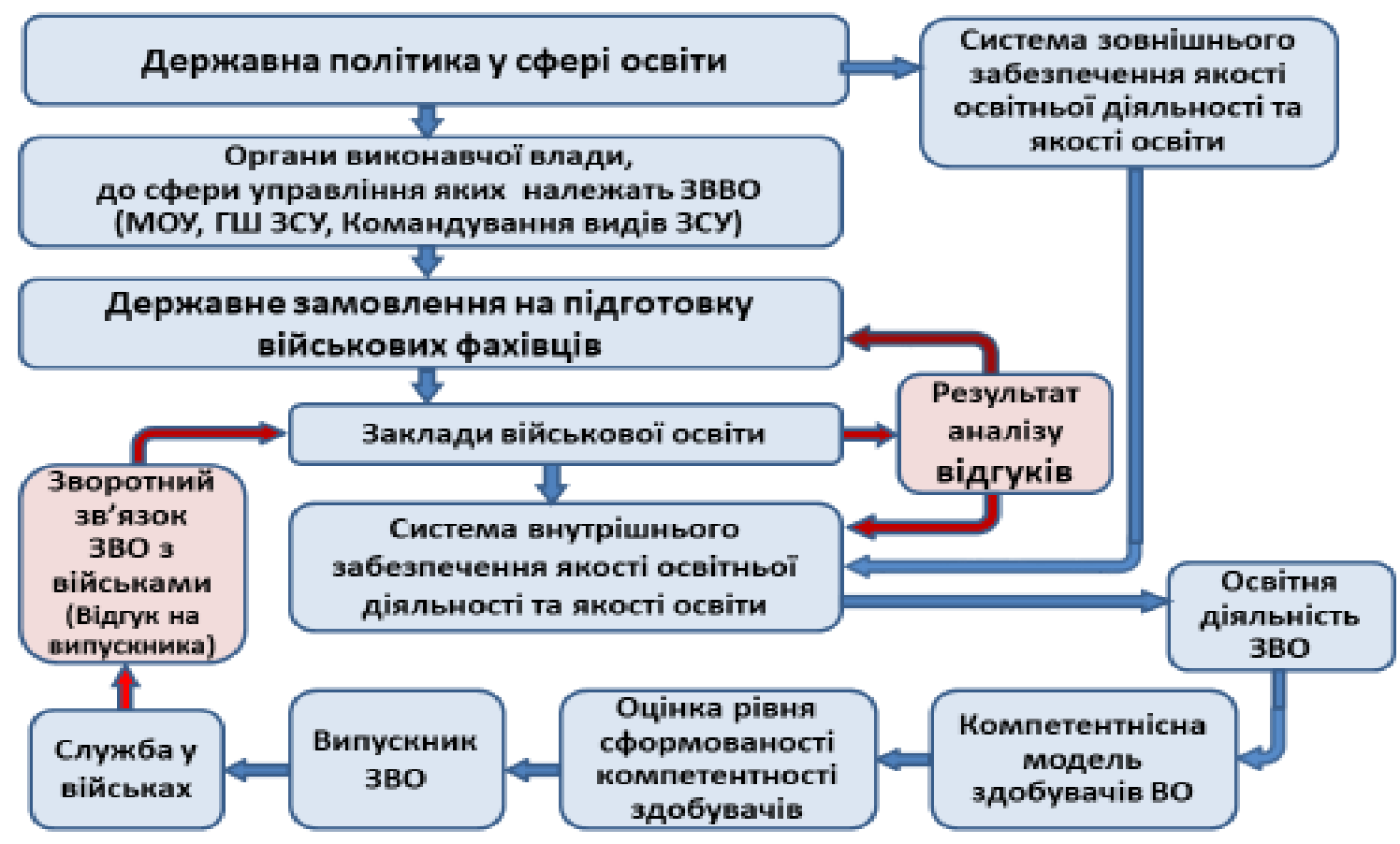

Рис. 1 Зворотний зв’язок у системі управління якістю військової освіти

При цьому варто наголосити, що виконання зазначеного державного замовлення відбувається у змінюваних умовах зовнішнього та внутрішнього середовищ і потребує розроблення та впровадження в практику військової школи певних підходів, пов'язаних із змістовим наповненням поняття “управління змінами" та особливостями його застосування в освітній діяльності 3ВО. Дефінітивний аналіз цього поняття наведено у працях вітчизняних вчених I. Бажина, T. Пічугіної, I. Семенець-Орлової [1-3] та інших науковців. Зокрема, управління змінами розглядається як вид професійної діяльності на основі застосування структурного підходу щодо переведення індивідів та організацій 3 поточного в бажаний майбутній стан. Завдання управління змінами полягатиме в тому, щоб правильно оцінити сутність процесів, які відбуваються у зовнішньому середовищі, відібрати і впровадити нововведення, що допоможе звести всі зовнішні та внутрішні види впливу до єдиної лінії поведінки, зберегти або підвищити ефективність діяльності відповідних структур [2, С. 7].

Таким чином, проблему управління змінами, яка полягатиме у подоланні відмінностей між бажаним і наявним станом відповідної сфери діяльності, потрібно вирішувати шляхом реалізації певної стратегії (стратегій), розроблення та прийняття якої відповідатиме стратегічному рішенню особи чи органу, які відповідальні за прийняття та реалізацію такого рішення.

За результатами проведеного аналізу поняття “управління змінами” та 3 урахуванням особливостей функціонування СВО надаємо визначення поняття, що адаптоване до сфери військової освіти: управління змінами в системі військової освіти - це цілеспрямована діяльність центральних органів виконавчої влади, керівництва Міністерства оборони України, Генерального 
штабу ЗС України та органів управління військовою освітою на усіх рівнях щодо своєчасного переведення $\mathrm{CBO}$ із поточного стану в необхідний у мінливих умовах зовнішнього та внутрішнього середовищ іiі функціонування [4, С. 119-120; 5, С. 46-55]. Важливе місце в управлінні змінами СВО посідає зворотний зв'язок закладів військової освіти з військами (силами), та його складова - відгук на випускника, в основу якого покладається компетентнісна модель військового фахівця. У зазначеній моделі представлені основні компетентності, які мають бути сформовані за результатами навчання здобувача освіти у ЗВО та відповідні професійно важливі якості. Компетентність (від лат. competens (competentis) - належний, відповідний), компетентний - той, що знає, володіє необхідною інформацією, авторитетний у чомусь. Поняття "компетентність" у Законі України "Про вищу освіту" представлене як здатність особи успішно соціалізуватися, навчатися, провадити професійну діяльність, яка виникає на основі динамічної комбінації знань, умінь, навичок, способів мислення, поглядів, цінностей, інших особистих якостей [6].

Відповідно до міжнародного стандарту ISO 9000, поняття “компетентність” визначається як доведена здатність особистості застосовувати знання і навички задля досягнення визначених результатів.

Інтерпретацію наведених понять, з урахуванням особливостей військової служби можна визначити так: компетентність $\epsilon$ інтегральним показником якості підготовки військового фахівця як доведена ним здатність до постійного самовдосконалення та самоосвіти, готовність застосовувати сформовані знання, уміння, навички, інші професійно важливі якості і ціннісні орієнтації при виконанні службових (бойових) функцій у військах (силах) в умовах мирного, воєнного часу та в особливий період на посаді призначення задля досягнення визначених результатів [7, С.92-103].

Рівень сформованості основних компетентностей випускника визначається за результатами їх оцінювання безпосереднім командиром, який готує відгук на випускника, шляхом внесення позначки “+” у відповідний стовпчик (дивись таблицю 1) за 5-ти бальною шкалою: “5”, “4”, “3”, “2”, “0”, де: “5” найвищий бал (“відмінно”), “2” - найнижчий бал (“незадовільно”), а “-” - якість не проявилася.

Відгук у цифровому вигляді надсилається електронною поштою замовнику та в заклад військової освіти, де перші дві цифри - №№ компетентностей, а третя - оцінка в балах (наприклад: $3.1 / 5 ; 3.2 / 4 ; 3.3 / 3 ; 3.4 / 3 ; 3.5 / 3$ ). Далі, у 3ВО із використанням відповідної програми та застосуванням методів кваліметрії (кількісна оцінка якості) підраховується середній показник за випускників даного рівня підготовки (у \%) за кожною ПВЯ та рівень сформованості інтегральної компетентності (Рис.2). Подібний підхід уможливлює проведення системного аналізу результатів зворотного зв'язку і дозволяє визначати внесок кожної кафедри за кожною дисципліною у підготовку кожного військового фахівця 


\section{Відгук на випускника ВВНЗ - тактичний рівень}

(варіант формалізованого бланку, фрагмент)

Таблищчі 1

\begin{tabular}{|c|c|c|c|c|c|c|}
\hline \multirow{2}{*}{$\begin{array}{l}\text { № } \\
\text { 3/ח }\end{array}$} & \multirow{2}{*}{$\begin{array}{l}\text { Компетентності та професійно важливі якості } \\
\text { (ПВЯ) }\end{array}$} & \multicolumn{5}{|c|}{$\begin{array}{c}\text { Результати } \\
\text { оцінювання(бали) }\end{array}$} \\
\hline & & 5 & 4 & 3 & 2 & 1 \\
\hline \multicolumn{7}{|c|}{ 3. Військово-технічна (здатність): } \\
\hline 3.1. & $\begin{array}{l}\text { володіти всіма видами озброєння і військової техніки } \\
\text { підрозділу }\end{array}$ & + & & & & \\
\hline 3.2. & $\begin{array}{l}\text { забезпечувати правильну експлуатацію озброєння та } \\
\text { військової техніки підрозділу, їі обслуговування i } \\
\text { збереження }\end{array}$ & & + & & & \\
\hline 3.3. & $\begin{array}{l}\text { особисто перевіряти наявність, технічний стан бойову } \\
\text { готовність штатної техніки та озброєння }\end{array}$ & & & + & & \\
\hline 3.4. & $\begin{array}{l}\text { готувати штатне озброєння і військову техніку до } \\
\text { виконання бойових задач, виходу на кожне навчання чи } \\
\text { заняття }\end{array}$ & & & + & & \\
\hline 3.5 & проводити паркові дні & & & + & & \\
\hline
\end{tabular}

У таблиці 1 наведено один 3 фрагментів відгуку на випускника ЗВО тактичного рівня підготовки. Застосування комплексного підходу дозволить вийти на певні узагальнення і визначити інтегральну компетентність (Рис. 2), що сприятиме оптимізації діяльності суб'єктів освітнього процесу ЗВО щодо забезпечення і гарантування якості підготовки військових фахівців.

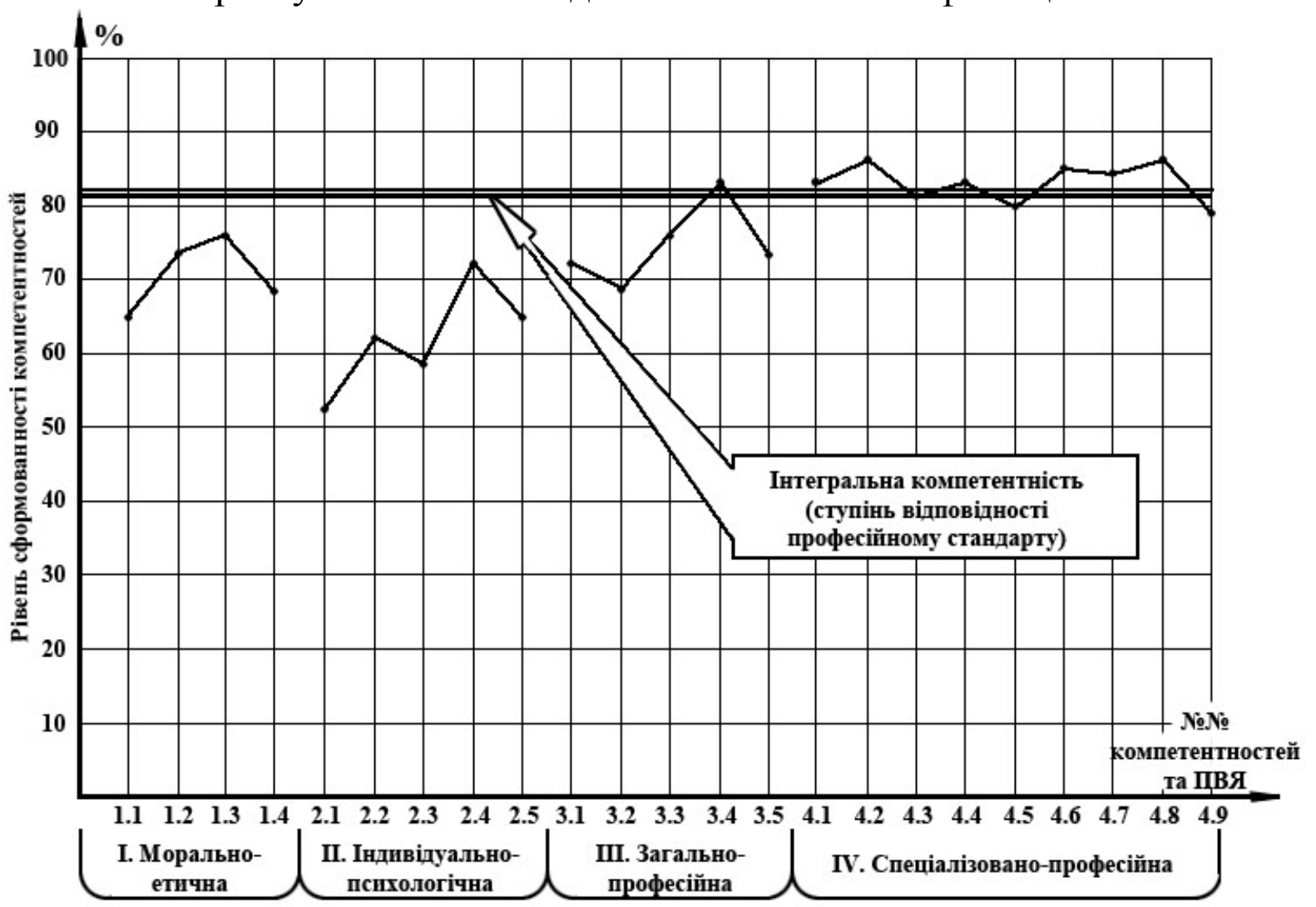

Рис. 2 Результати оцінювання рівня сформованості компетентностей у випускника ВВНЗ (фрагмент) за результатами його службової діяльності у військах (відгук на випускника) 
Висновок. Таким чином, у статті розкрито сутність зворотного зв'язку, досліджено його роль і місце як обов'язкової складової процесу управління змінами у системі військової освіти. Розглянуто типи зворотних зв'язків (позитивні, негативні) щодо характеру впливу на систему військової освіти. Наголошено, що застосування зворотного зв'язку в СВО дає можливість систематично відстежувати ефективність процесів та доцільність і обгрунтованість прийнятих рішень, відповідність отриманих результатів тим, що передбачалися та сприяє виявленню відхилень від запланованих параметрів та усуненню несприятливих наслідків функціонування системи військової освіти.

\section{ЛІТЕРАТУРА}

1. Бажсин I. I. Управління змінами / І. І. Бажин. - Харків: Консум, 2006. - 384 с.

2. Пічугіна Т. С. Управління змінами: навч. пос. / Т. С. Пічугіна, С. С. Ткачова, О. П. Ткаченко.- Харків: ХДУХТ, 2017. - 226 с.

3. Семенець-Орлова I. А. Державне управління освітніми змінами в Україні: теоретичні засади: монографія. - К.: ЮСТОН, 2018. - 420 с.

4. Зельнииький А. М., Заболотний О.А. Наукові підходи до управління змінами в системі вищої військової освіти у Збройних Силах України // Збірник наукових праць Центру воєнно-стратегічних досліджень НУОУ імені Івана Черняховського. - 2019. - № 3 (67). C. $115-122$.

5. Зельницький А. М., Заболотний О. А., Васильєв О. М. Паламар М. І. Вища освіта як цілісна система: концептуальні засади їі розвитку та управління змінами // Наука і оборона. 2020. - № 3. - С. 46 - 55.

6. Закон України "Про вищу освіту” від 1.07.2014 № 1556-VII. // Відомості Верховної Ради. - 2014. - № 37 - 38. - Ст. 2004.

7. Заболотний О. А., Зельницький А. М. та ін. Кадровий потенціал збройних сил і якість вищої військової освіти: аналіз понять та система зв'язків // Збірник наукових праць “Військова освіта” НУОУ імені Івана Черняховського. - 2018. - № 2 (38). - С. 92 - 103.

\section{REFERENCES}

1. Bazhyn I. I. Change Management/ I. I. Bazhyn. - Kharkiv: Konsum, 2006. - 384 p.

2. Пічугіна T. С. Управління змінами: навч. пос. / Т. С. Пічугіна, С. С. Ткачова, О. П. Ткаченко.- Харків: ХДУХТ, 2017. - 226 с.

3.Semenets-Orlova I. A. State management of educational changes in Ukraine: theoretical principles: monograph. - K.: YUSTON, 2018. -420 p.

4. Zelnytskyi A. M., Zabolotnyi O.A. Scientific Approaches to Change Management in the System of Higher Military Education in the Armed Forces of Ukraine // Collection of scientific works of Center of Military and Strategic Studies NDU of Ukraine named after Ivan Cherniakhovskyi. - 2019. - № 3 (67). - P. 115 - 122.

5. Zelnytskyi A. M., Zabolotnyi O. A., Vasyliev O. M., Palamar M. I. Higher education as a holistic system: conceptual foundations of its development and change management // Science and Defence. - 2020. - № 3. - P. 46 - 55.

6. Law of Ukraine “On Higher Education” 1.07.2014 № 1556-VII. // Information of the Verkhovna Rada. - 2014. - № 37 - 38. - С T. 2004.

7. Zabolotnyi O.A., Zelnytskyi A. M.and others. Personnel potential of the armed forces and the quality of higher military education: analysis of concepts and system of relations // Collection of scientific works "Military Education" NDU of Ukraine named after Ivan Cherniakhovskyi. 2018. - № 2 (38). - P. 92 - 103. 


\section{PЕЗЮМЕ}

Андрей Зельницкий, кандидат педагогических наук, профессор Национальный университет обороны Украины имени Ивана Черняховского

\section{Обратная связь как компонент управления изменениями в системе военного образования}

В статье определень роль и место обратной связи в системе военного образования в контексте перевода данной системы из текущего состояния в необходимое (желательное) состояние (управления изменениями) в условиях влияния определенных факторов внешней $u$ внутренней среды, предложены подходы $\kappa$ формированию содержания отзыва на выпускника военно-учебного заведения как составляющей обратной связи, а также методика оценивания уровня сформированности соответствующих компетентностей $u$ профессионально-важных качеств у выпускника по результатам его служебной деятельности в войсках (силах).

Ключевые слова: управление изменениями; образовательный прочесс; обратная связь; военно-учебные заведения; система военного образования.

\section{SUMMARY}

Andrii Zelnytskyi, $\mathrm{PhD}$ (Pedagogical Sciences), Professor National Defence University of Ukraine named after Ivan Cherniakhovskyi

\section{Feedback as a component of change management in the system of military education}

Introduction. The articles deals with defining role and place of feedback in the change management system concerning its transition from the current state to the required (desired) state under the influence of certain factors of external and internal environment. The article also proposes a feedback content on the HEI's graduate as a component of feedback and assessing of the certain competencies formation level and professionally important qualities of the graduate HEI as a result of his/her service in the army.

Purpose. The purpose of the article is to study the role, place and essence of feedback as component of the change management process in the military education system and consider the theoretical basis for solving this problem.

Methods. The study was conducted using the following theoretical methods: systems analysis and synthesis, induction and deduction, comparison, classification, generalization and systematization.

Results. The role, place and content of the response about the graduate of IHE are studied as a component of feedback on change management in the military education system.

Originality. The problem of change management in the military education system and feedback on its functioning is considered in the framework of quality of military specialists' training for the Armed Forces of Ukraine and other military formation.

Conclusion. The article identifies the general problem of change management in the IHE as a systematic and gradual overcoming of differences between the current state of military education, which does not fully meet the real and potential needs of the Defense Forces concerning formation and enhancement of personnel's potential, and its desired state, which should meet the long-term model of defense forces development and new challenges facing society, the state, the Armed Forces 
of Ukraine and other components of the defense forces, military education in changing internal and external environments and which need to respond promptly and adequately.

Key words: change management; educational process; feedback; military educational institutions; military education system. 